\title{
Assessment of Self-identified Learning Outcomes by Candidates in an Online Professional Program Curriculum Leadership Course
}

\author{
Olajide O. Agunloye ${ }^{1}$ \\ ${ }^{1}$ College of Education, Augusta University, Augusta, Georgia, USA \\ Correspondence: Olajide O. Agunloye, Department of Teaching and Leading, College of Education, Summerville \\ Campus, August University, 2500 Walton Way, Augusta, GA 30094, USA.
}

Received: February 12, 2018

Accepted: March 6, 2018

Online Published: April 17, 2018

doi:10.5430/irhe.v3n2p26

URL: https://doi.org/10.5430/irhe.v3n2p26

\begin{abstract}
Learning outcomes are expected actions depicting the knowledge, skills, and dispositions (KSD) students can demonstrate at the end of a course or a unit of study relevant to the context of professional practice and institutional expectations. In professional graduate courses, learning outcomes cannot be limited to scores on classroom assessments only. It is defined by what students are taking away, during and at the end of the course, to inform professional practice. Candidates in professional programs should be provided the opportunity to self-identify and self-define learning outcomes that are relevant to their respective contexts of professional practice in the courses they take. This makes the assessment of learning outcomes a bit more challenging in professional programs and courses than non-professional programs. This is particularly so in an online course-delivery format for professional programs. This Scholarship of Teaching and Learning (SoTL) study analyses and assesses specific self-identified learning outcomes by candidates in an online professional graduate course. The study categorizes and describes specific learning outcomes that candidates self-identified and suggest ways these can be used to improve the content, design, learning outcomes, and expectations in an online graduate-level professional program course. The need for further research in this area is emphasized.
\end{abstract}

Keywords: professional programs, course design and delivery, knowledge, skills, dispositions, learning outcomes

\section{Introduction}

Enrollment in online programs and courses in higher education in the United States is growing. Between 2002 and 2011, enrollment in online course increased from 9.0\% to 32.0\% of total enrollment (Allen \& Seaman, 2013). Allen and Seaman also indicated that $50 \%$ of candidates seeking higher education express interest in online course offerings. Growing enrolment in online courses calls for increasing need for assessment of learning outcomes in courses delivered through online learning platforms, especially in professional graduate programs. In the context of this study the words 'candidate', 'student', and 'learner' carry the same meaning and are used interchangeability.

\subsection{Defining and Defining Learning Outcomes}

Learning outcomes are statements of expected actions that describe the knowledge, skills, and dispositions (KSD) that students can demonstrate at the end of a course or a unit of study. Assessment of learning outcomes in courses is very important to determine the impact on students in terms of usage and application of the KSD gained because of the learning experiences in the course. Practices in deterring learning outcomes in a course are generally based on scores or grades earned by the learners on tests taken during and at the end of the course. These pose problems in determining the scope and extent of the impact of learning on students in the context of their practice, especially for candidates in professional programs.

\subsection{Challenges in Determining Learning Outcomes}

Often, scores or grades earned by the learners on tests taken during and at the end of a course, do not provide much detail about the changes in KSD by the learners in the context of professional practice. This is more so in online graduate professional courses. Determining learning outcomes in courses offered in professional-practice programs is even more complex because is need for contextual relevance of learning for candidates to better inform and improve professional practice. 


\subsection{Purpose of Study}

The purpose of this study is to assess specific self-identified learning outcomes by candidates in an online graduate-level professional program curriculum leadership course in the context of their professional practice. The study is aimed to: identify, categorize and describe specific self-defined learning outcomes; explore any alignment of candidates' self-identified outcomes with stated learning goals for the course; explore any alignment of candidates' self-identified learning outcomes align with institutional conceptual educational outcome expectations; use finding to suggest improvements in course content, design, and outcome expectations for candidates in professional graduate programs.

\subsection{Relevant Scholarship}

The purpose of this study is to assess specific self-identified learning outcomes by candidates in an online graduate-level professional program curriculum leadership course in the context of their professional practice. Learning outcomes can be defined in three major ways. First, learning outcomes can be defined as the desired knowledge, skills, behavior, disposition that are aligned to instructional purpose and mission which students are expected to take away at the end of an educational experience (Abbott, 2014; Ludwig, 2009;). Second, learning outcome can be defined as the knowledge, skills, and dispositions (KSD) that students take away at the end of an educational experience based on their interaction with the learning process (Oster \& Tiu, 2014). Third, learning outcome can be defined as what the institution/program has accomplished in terms of overall learning experience of students both within and outside of the learning environment (Oster \& Tiu, 2014; Abbott, 2014). In the context of this study, this author defines learning outcome as expected actions that depicts the knowledge, skills, and dispositions (KSD) that students demonstrate at the end of a course or unit of study relevant to context of their professional practice and institutional expectations for candidates' success.

Most of the studies in learning outcomes are based on student scores in unit assessments or assessments given at the end of the course (Figilo, Rush, \& Yin, 2010; Leaonard \& Brown, 2013; Means, Totama, Murphy, et al., 2010). In professional-practice programs, students are trained to be become practitioners with focus on authentic application of KSD gained in solving problems of practice and improving the practice of the profession. There is very limited published studies on self-identified learning outcomes in online courses designed for professional programs. The purpose of this study is to assess specific self-identified learning outcomes by candidates in an online graduate-level professional program curriculum leadership course in the context of their professional practice.

\subsection{Research Question}

The study is designed to answer the following questions:

Are there specific learning outcomes that professional graduate students can self-identify in an online curriculum leadership course?

How do the self-identified learning outcomes align with pre-state expected learning goals for the curse?

How do the self-identified learning outcomes align with stated institutional expected learning outcomes?

How can candidates' self-identified learning outcomes be used to improve the content, design, pedagogy and delivery of graduate-level professional program online courses?

\section{Method}

This is a Scholarship of Teaching and Learning (SoTL) study, grounded in constructivist paradigm framework (Guba \& Lincoln; Lynham \& Guba, 2011) and positivist epistemological construct (Gall, Gall, \& Borg, 2007). The constructivist framework is relevant in three ways. First, there is close instructional interaction between the researcher and subjects. Second, individual subjects are allowed the freedom to express multi-perspective constructs and thoughts in the context of the study (Bruner, 1986). Third, the goal of the study is to create categorization and reconstruction of thoughts and reflections grounded in the data summarized from subject's responses (Creswell, 2012; Staruss \& Corbin, 1998). The positivist construct of the study is highlighted by the proportional analysis and representation of the occurrence of types of descriptives from research subjects' responses. The two approaches interact to expand the expressed reflective thoughts of the subjects into more causal reality. The study approach is a therefore a mixed-method case study that probes both the exploratory and confirmatory aspects of its purpose (Johnson \& Onwuegbuzie, 2004). 


\subsection{Characteristics of Participants and Sample Size}

Participants were 27 candidates in the professional educational leadership program. The candidates registered for and completed an online curriculum leadership course during spring semesters only over three years between 2013 and 2015. The course is offered once in an academic year. Ten students took the course in 2013, ten in 2015 and seven in 2015. No substantive changes were made to the course over the three years in terms of goals, expectations, required activities and assignments.

\subsection{Measures and Analysis Approach}

During each semester of the course, candidates (participants) were directed to respond to open-ended survey questions on learning outcomes that solicit free responses from the perspectives of the participants in the context of professional practice (see Appendix 1 for survey instrument). The survey instrument was embedded within the 'survey' portal of the online learning platform as a non-graded voluntary feedback instrument. All the 27 students who complete the course responded to the survey.

Response statements from participants were dimensionally summarized, analyzed and categorized into themes, domains, and constructs in the context of professional practice. The categorization was based on phenomenological phrases that share sufficiently obvious similarities as used in the responses. The themes and domains were grounded in the response from statements relating to professional practice and problems of practices. Quantitative measures were assigned to each category based on the occurrence of discernable professional phenomenological outcome phrases expressed by the participants. The categories were then analyzed quantitatively for relative preponderance of discernable phenomenological outcome phrases used.

\section{Results}

The responses were first categorized into outcome themes (Table 1). The three major themes that emerged were Professional Knowledge, Professional Skills, and Professional Dispositions. Five outcome domains were identified under Professional Knowledge. The five were Content Knowledge (CNT); Research, Theories, and Models (RTM); Curriculum Factors and Forces (CFF); Curriculum goals and Standards (CGS); and Curriculum and Instruction Interphase (CII). The five outcome domains identified under Professional Skills were Curriculum Evaluation (CRE); Application of Theory to Practice (ATP); Reflective Skills (RFS); Curriculum Leadership (CLD); and Curriculum and Instruction Interphase CII). The four domains identified under Professional Dispositions were Professional Development Disposition (PDD); Reflective Practices Disposition (RFD); General Leadership Disposition (GLD); Curriculum and Instruction Interphase (CII).

Table 1. Outcome themes, domains, and constructs

\begin{tabular}{|c|c|c|c|c|c|c|c|c|c|c|c|c|c|c|}
\hline Outcome & \multicolumn{5}{|c|}{ Professional Knowledge } & \multicolumn{5}{|c|}{ Professional Skills } & \multicolumn{4}{|c|}{ Professional Dispositions } \\
\hline $\begin{array}{l}\text { Outcome } \\
\text { Domain/ }\end{array}$ & CNT & RTM & CFF & CGS & CII & CRE & ATP & RFS & CLD & CII & PDD & RFD & GLD & CII \\
\hline Responses & 5 & 34 & 18 & 3 & 9 & 3 & 7 & 5 & 30 & 21 & 16 & 10 & 15 & 5 \\
\hline Total & \multicolumn{5}{|c|}{64} & \multicolumn{5}{|c|}{66} & \multicolumn{4}{|c|}{46} \\
\hline KEY & \multicolumn{5}{|c|}{$\begin{array}{l}\text { CTN = Content } \\
\text { RTM = Research, Theories, and } \\
\text { Models } \\
\text { CFF = Curriculum Factors and } \\
\text { Forces } \\
\text { CGS = Curriculum Goals and } \\
\text { Standards } \\
\text { CII = Curriculum-Instruction } \\
\text { Interphase }\end{array}$} & \multicolumn{5}{|c|}{$\begin{array}{l}\mathrm{CRE}=\text { Curriculum Evaluation } \\
\text { ATP = Application of Theory to } \\
\text { Practice } \\
\text { RFS = Reflective Skills } \\
\text { CLD = Curriculum Leadership } \\
\text { CII = Curriculum-Instruction } \\
\text { Interphase }\end{array}$} & \multicolumn{4}{|c|}{$\begin{array}{l}\text { PDD = Professional } \\
\text { Development Disposition } \\
\text { RPD = Reflective Practices } \\
\text { Disposition } \\
\text { GLD = General Leadership } \\
\text { Disposition } \\
\text { CII = Curriculum-Instruction } \\
\text { Interphase Disposition. }\end{array}$} \\
\hline
\end{tabular}


Professional Skills theme has the highest number of outcome descriptive phrases (66 mentions), followed by Professional Knowledge theme (64 mentions). Professional Dispositions theme also has a relatively high number of outcome descriptive phrases (46 mention). Each of the themes were further organized into domain levels to establish the dimensionality of constituent domains and constructs.

\subsection{Professional Knowledge Theme}

The professional knowledge theme, as categorized by domains of knowledge self-identified in candidates' responses, is dimensionally analyzed and shown in Figure 1.

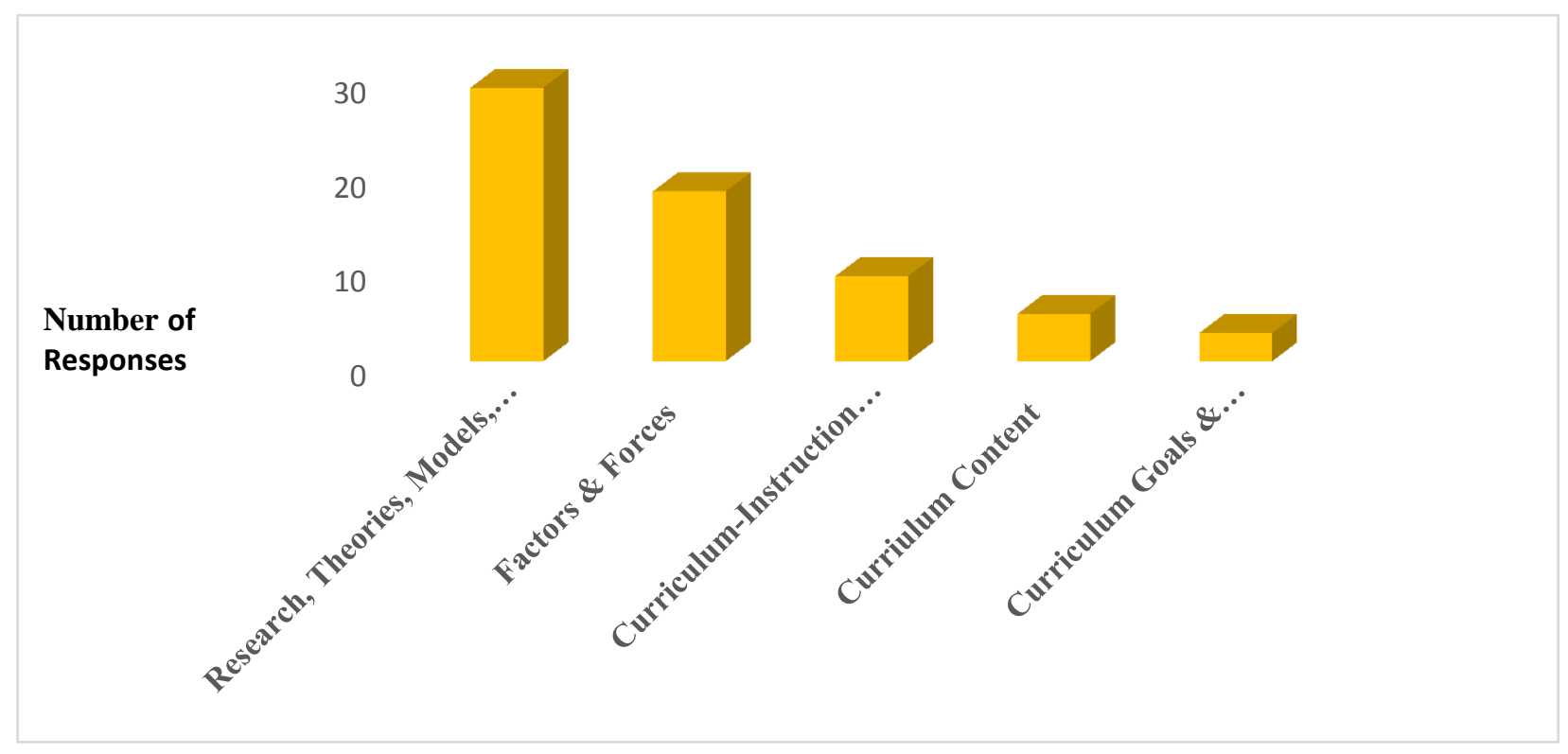

Figure 1. Domains of professional knowledge outcome theme

Knowledge of curriculum research, theories and models (RTM) was the most mentioned response (29 mentions) under the Professional Knowledge theme; followed by knowledge of factors and forces (CFF) affecting curriculum development (18 mentions). The knowledge of the interphase between curriculum and instruction (CII) was also relatively mentioned frequently (9 mentions). Knowledge of curriculum goals and standards (CGS) was the least mentioned in the responses ( 3 mentions).

\subsection{Professional Skills Theme}

Professional Skills theme has five domains (Figure 2). Curriculum leadership (CLD) response phrases was the most predominant skills outcome stated in response descriptive (30 mentions). Curriculum-instruction interphase (CII) and the application of curriculum theories in practice (ATP) were next with significantly lower responses ( 9 and 7 mentions respectively). Under the Curriculum Leadership domain, the 'improved curriculum evaluation ability' ( 8 mentions) and 'how to effectively implement curriculum' (6 mentions) were the prevalent responses. 'Ability to align curriculum across contents' (7 mentions) and 'ability to adapt curriculum to meet the needs of students' (7 mentions) were the predominant outcome responses under the Curriculum-Instruction Interphase domain. Students also stressed that applying curriculum theory, concepts, and research to real-life situations ( 7 mentions) was an important stated outcome under Application of Theory to Practice. 


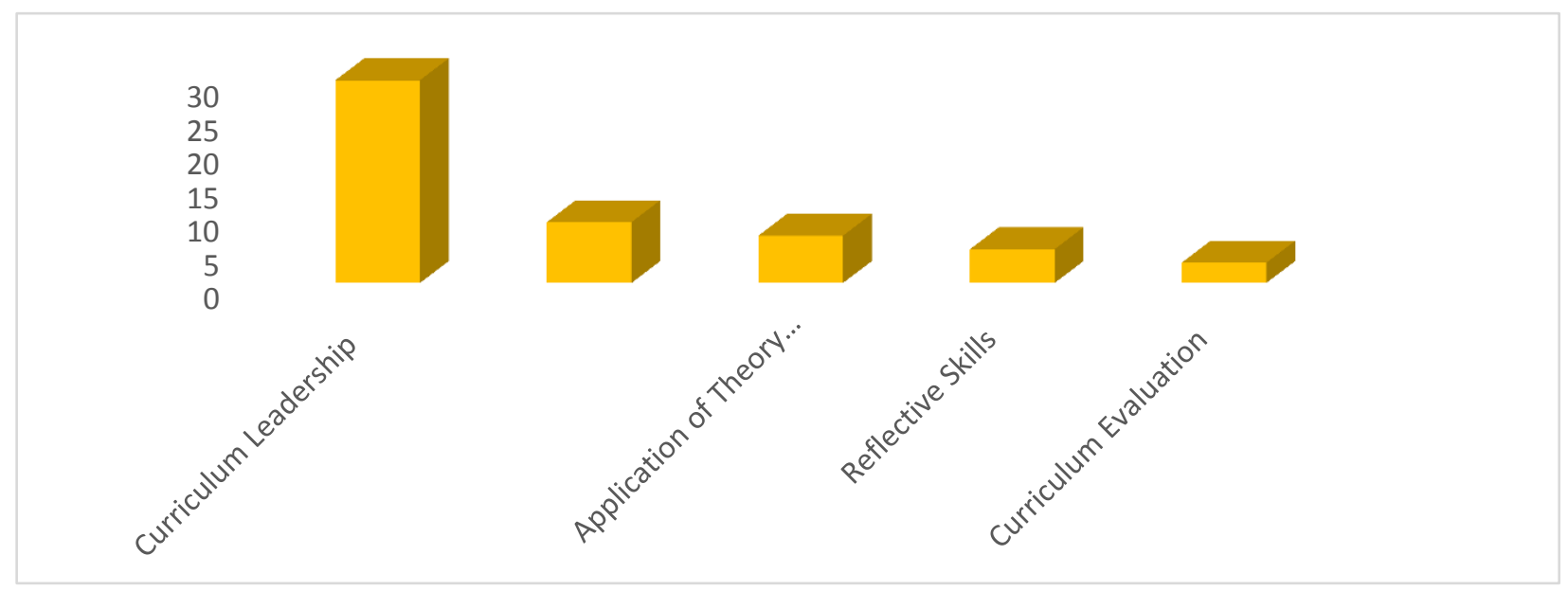

Figure 2. Domains of professional skills theme

\subsection{Professional Dispositions Theme}

The response descriptive phrases and their corresponding scores (occurrence) for the Professional Dispositions theme are shown in Figure 3. This theme has four domains as shown in Figure 3.

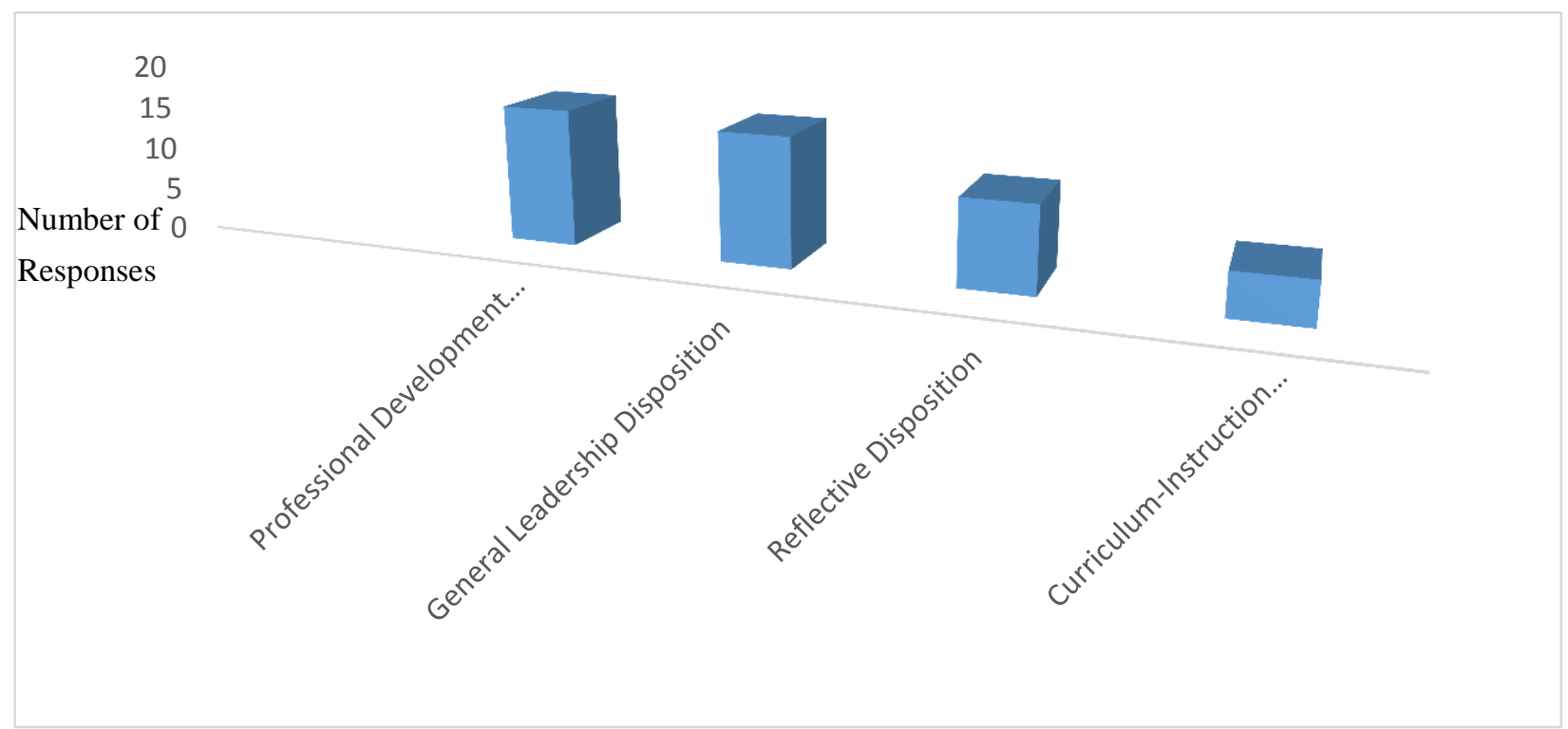

Figure 3. Domains of professional dispositions theme

Professional Development Disposition was the predominant disposition outcome stated in the response descriptive (16 mentions), followed by General Leadership Dispositions (15 mentions). Reflective Disposition (10 mentions) and Curriculum-instruction Interphase Disposition ( 5 mention) were also indicated. Under Professional Development Disposition the top descriptive phrase was 'better ability to support teachers to improve professional knowledge and skills' (12 mentions). Under General Leadership Dispositions, the prominent outcome descriptive was 'becoming more effective leader and administrator' (6 mentions). Under Reflective Dispositions, 'thinking out the entire process involved in curriculum development' (5 mentions) was the leading outcome descriptive. 


\subsection{Concordance Analysis of Course-Goals Versus Self-identified Outcomes}

The next step in the analysis of the results was to explore the concordance or discordance of pre-stated course goals with student self-identified learning outcome. See Table 5. There were three areas in which there was concordance between pre-stated learning goals/outcomes for the curriculum leadership course and the self-identified learning outcomes stated by the candidates. The first area was under the Professional Knowledge Theme. The pre-stated course goal was for students to be able to 'identify and explain various models of curriculum development'. This goal is in concordance with candidate's self-defined learning outcome of 'knowledge and understanding of research, theories, models, and processes for curriculum development'. The two other areas of concordance were under Professional Skills. The first pre-stated learning goal was 'demonstrate understanding of the procedures involved in curriculum evaluation'. This is in concordance with candidates' self-defined learning outcome of 'ability to analyze curriculum for validity and reliability'. The second concordant pre-stated learning goal was 'demonstrate leadership skills needed for effective curriculum development, implementation, and evaluation. This is in concordance with candidates' self-defined learning outcome of 'demonstrate leadership skills to lead the development and implement effective curriculum'.

Table 2. Concordance analysis of course goals with self-identified learning outcome

\begin{tabular}{|c|c|c|c|}
\hline Themes & Pre-Stated Course Goals & Self-defined Course Outcomes by Students & $\begin{array}{l}\text { Number of } \\
\text { Response } \\
\text { phrases }\end{array}$ \\
\hline \multirow[t]{5}{*}{$\begin{array}{l}\text { Professional } \\
\text { Knowledge }\end{array}$} & \multirow[t]{4}{*}{$\begin{array}{l}\text { *Identify and explain various models for } \\
\text { curriculum development }\end{array}$} & $\begin{array}{l}\text { *Understanding and knowledge of research, } \\
\text { theories, models, and processes }\end{array}$ & $* 29$ \\
\hline & & $\begin{array}{l}\text { Better knowledge of curriculum-instruction } \\
\text { interphase }\end{array}$ & 9 \\
\hline & & Understanding of other curricular content areas & 5 \\
\hline & & Better Knowledge of curriculum standards & 3 \\
\hline & $* *$ None & $\begin{array}{l}\text { **Knowledge of factors and forces influencing } \\
\text { curriculum development }\end{array}$ & $* * 18$ \\
\hline \multirow[t]{6}{*}{$\begin{array}{l}\text { Professional } \\
\text { Skills }\end{array}$} & $\begin{array}{l}* * \text { Demonstrate understanding of the } \\
\text { contexts for curriculum development }\end{array}$ & $* *$ None & \\
\hline & $\begin{array}{l}\text { *Demonstrate understanding of the } \\
\text { procedures involved in curriculum } \\
\text { evaluation }\end{array}$ & $\begin{array}{l}\text { *Ability to analyze curriculum for validity and } \\
\text { reliability }\end{array}$ & $* 3$ \\
\hline & $* *$ None & $\begin{array}{l}\text { **Apply curriculum theory, concepts, and } \\
\text { research to real-life situations }\end{array}$ & $* * 7$ \\
\hline & $\begin{array}{l}\text { *Demonstrate leadership skills needed for } \\
\text { effective curriculum development, } \\
\text { implementation, and evaluation. }\end{array}$ & $\begin{array}{l}\text { *Demonstration of leadership skills to lead the } \\
\text { development and implementation of effective } \\
\text { curriculum }\end{array}$ & $* 30$ \\
\hline & $\begin{array}{l}\text { **Articulate the relevance of Standards in } \\
\text { curriculum development planning }\end{array}$ & $* *$ None & $* *$ \\
\hline & **None & $\begin{array}{l}* * \text { Demonstrate understanding of } \\
\text { curriculum-instruction interphase }\end{array}$ & $* * 9$ \\
\hline \multirow[t]{2}{*}{$\begin{array}{l}\text { Professional } \\
\text { Dispositions }\end{array}$} & \multirow[t]{2}{*}{$* *$ None } & $\begin{array}{l}\text { **Increased interest in Professional } \\
\text { Development for self and others }\end{array}$ & $* * 16$ \\
\hline & & $\begin{array}{l}* * \text { Improved reflections on professional } \\
\text { practices }\end{array}$ & $* * 10$ \\
\hline
\end{tabular}




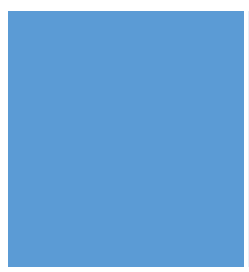

\begin{tabular}{l|l} 
**Improved general leadership practices & $* * 15$ \\
\hline **Improved clarity on the & $* * 5$ \\
$\begin{array}{l}\text { curriculum-instructional interphase } \\
\text { **Enabled me to keep an eye on diversity }\end{array}$ & $* * 1$ \\
regarding curriculum &
\end{tabular}

* Areas of high concordance noted for maintenance in course learning goals

**Areas of discordance noted for further improvement to course learning goals

The areas of discordance were eye-opening. No learning outcome goals were pre-stated for Professional Dispositions. Candidates indicated this as a self-identified learning outcome theme for this course. There were two significant self-identified learning outcomes stated by candidates under Professional Depositions that were not part of the pre-stated learning outcome goals. 'Increased interest in professional development for self and others' and improved general leadership practices'. These along with other self-identified learning outcomes, that were not part of the pre-determined learning goals, constitute positive unintended learning outcomes for candidates.

\subsection{Institutional Outcome Expectation and Self-identified Learning Outcomes}

Analysis was conducted to explore the relationship between pre-stated instructional outcomes expectations for the College of Education and the candidates' self-identified learning outcomes (see Figure 4). There were three competencies on which the college based its student learning outcome expectations. Students who complete any professional program in the college are expected to be 'Prepared', 'Able' and 'Responsive'.

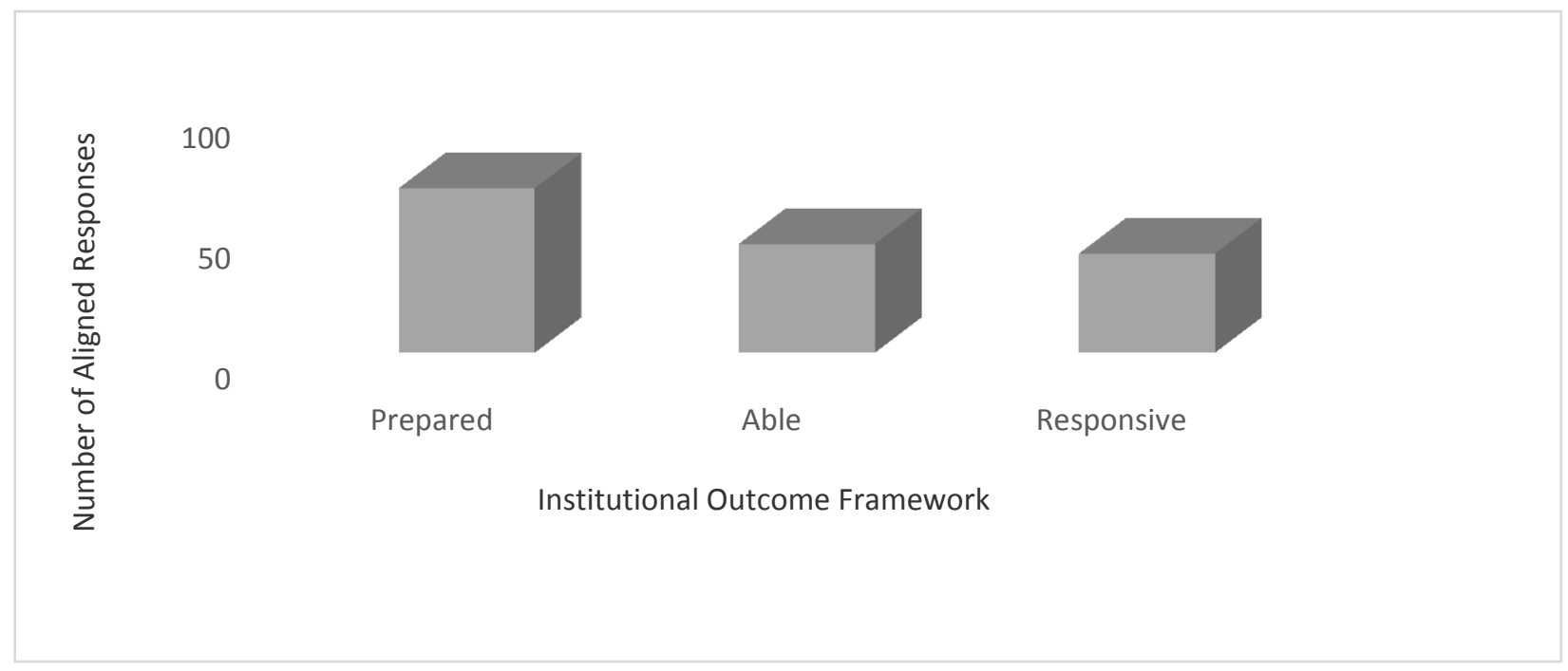

Figure 4. Institutional learning outcome expectations and candidates' self-defined learning outcomes

To be prepared is to be able to "think critically about the process of teaching, learning and assessment. 'Able' means that "students are creative, challenging, and flexible in professional practices". To be 'Responsive' means, that "students act in a manner that is empathetic, responsive, enthusiastic, inclusive and reflective in relations with stakeholders". Candidates' self-identified learning outcomes decretive occur most in the 'Prepared' institutional outcome expectation ( 65 mentions) followed by 'Able ( 40 mentions) and 'Responsive ( 35 mentions).

\section{Discussion}

Three major learning outcome themes are important in professional-practice programs such as educational leadership; professional knowledge, professional skills, and professional dispositions. In this study, majority of the self-identified learning outcomes by candidates were under professional knowledge and professional skills themes. 
These are the two outcomes that are easily measurable. Identifying and qualifying professional dispositions is sometimes abstractive and subjective. Under professional knowledge theme, the understanding of the research, theories, and processes that underpin curriculum development was the predominant outcome identified by candidates. This is the foundation on which curriculum development processes and leadership is anchored. Candidates' ability to get a good grasp of this process, as demonstrated in their self-identified learning outcomes, is indicative of a solid preparation foundation for curriculum leadership in their professional practice as educational leaders.

Under the professional skills theme, candidates' self-identified learning outcomes were more prominent in 'improved curriculum leadership' than in the other domains. Candidates in professional programs are required to engage in field-based performance activities and assignments in courses they take. Since the candidates were in a professional educational leadership program, a significant focused was placed on 'improved curriculum leadership', as indicated in the self-identified learning outcomes. This is in line with candidates' context of leadership practice. For professional dispositions theme, 'professional development' and general leadership deposition domains has significantly higher outcome response descriptives than others. These are positively unintended eureka learning outcomes of teaching this course. It is good to know that the course motivates candidates to seek professional growth and development for self and others as a result of taking this course.

There are candidates' self-identified learning outcomes by students that were not part of he pre-stated learning goals for the course. These include knowledge of factors and forces influencing curriculum'; 'application of curriculum theories, concepts, and research'; 'demonstrating understanding of curriculum-instruction' interphase; 'improved understanding for the need to encourage and support professional development for self and others'; 'improved knowledge of general leadership practices'; and 'improved reflections on professional practice'. These are positively unintended outcomes that will be part of pre-stated learning goals for the course.

There are also pre-stated learning goals that were not evident in candidates' self-identified learning outcomes. They include 'demonstrating understanding of the context of curriculum development'; and 'articulating the relevance of standards in curriculum development'. Attention needs to be paid to these learning goals to ensure that they are stressed in the design and delivery of the course. These are for further improvement to the course.

The findings indicate that this course substantially meets the expectations for the institutional learning outcome expectations of 'Prepared', 'Able' and 'Responsive'. The course achieved significantly more in in the Prepared outcome expectation than the Able and the Responsive. This may be because 'Able' and 'Responsive' are dependent on continuous professional-practice and growth, after completion of preparation program as candidates continue to horn their on-the-job professional practices.

It is the hope of the author that this study has provided some theoretical and practical basis for analyzing and determining learning outcomes in online professional programs courses, especially for a curriculum leadership course for education practitioners. Hopefully this will spark the beginning of further studies in SoTL in this area. The author is following up on this study with other online course in the educational administration and leadership program.

\section{References}

Abbott. (2014). Hidden curriculum: The glossary of education reform. Retrieved from http://edglossary.org/hidden-curriculum

Allen, I. E., \& Seaman, J. (2013). Changing course: Ten years of tracking online education in the United States. Babson Survey Research Group. Pearson Publishers and Sloan Foundation.

Brian, J., \& Ludwig, J. (2009). Improving educational outcome for poor children. In M. Cancian and S. Danziger (Eds.), Changing Poverty, Changing Policies (pp. 266-300). New York: Russell Sage Foundation Press.

Bruner, J. (1986). Actual minds, possible worlds. Cambridge, MA: Harvard University Press.

Creswell, J. W. (2012). Educational Research: Planning, conducting, and evaluating quantitative and qualitative research. Boston, MA: Pearson.

Figlio, D.N., Rush, M., \& Yin, L. (2010). Is it live or is it internet? Experimental estimates of the effects of online instruction on student learning. Working paper 16089, National Bureau of Economic Research, Cambridge, Ma. https://doi.org/10.3386/w16089

Gall, M. D., Gall, J. P., \& Borg, W. R. (2007). Educational research: An Introduction. Boston, MA: Pearson. 
Guba, E. G., \& Lincoln, Y. S. (2005). Paradigmatic controversies, contradictions, and emerging confluences. In N. K. Denzin \& Y. S. Lincoln (Eds.), Handbook of qualitative research (pp.105-117). Thousand Oaks, CA: Sage.

Johnson, R. B., \& Onwuegbuzie, A. J. (2004). Mixed methods research: A research paradigm whose time has come. Education Researcher, 337(7), 14-26. https://doi.org/10.3102/0013189X033007014

Lincoln, Y. S., Lynham, S. A., \& Guba, E. G. (2011). Paradigmatic controversies, contradictions, and emerging confluences, revisited. In N. K. Denzin \& Y. S. Lincoln (Eds.), The SAGE handbook of qualitative research (4 ed., pp.97-128). Thousand Oaks, CA: Sage.

Means, B., Toyama, Y., Murphy, R., Bakia, M., \& Jones, K. (2010). Evaluation of evidence based practices in online learning: A Meta-analysis and review of online learning studies. Washington: U.S. Department of Education.

Oster, S., \& Tiu, S. (2014). Writing Measurable Learning Outcomes. Retrieved from http://www.gavilan.edu/research/spd/Writing-Measurable-Learning-Outcomes.pdf

Strauss, A. L., \& Corbin, J. M. (1998). Basic qualitative research: Techniques and procedures for developing grounded theory. Thousand Oaks, CA: Sage.

\section{Appendix}

\section{Self-identified Learning Outcome Survey Instrument for a Professional Graduate Program Course}

Provide your reflective thoughts on each of the following course outcome description survey items:

1. What significant content knowledge have you gained in this course to inform your professional practice?

2. What significant professional skills have you acquired in this course?

3. Provide a summary reflection of what you have learned in this course relative to the context of your professional practice.

4. How you would use what you have learned to guide your professional practice to for improved effectiveness?

5. What do you like about the content and delivery of this course that inform your professional practice?

6. What improvements would you suggest for the course to enhance your professional practice? 